\title{
Use of Dermatoglyphic Parameters as Possible Markers in Bipolar Affective Disorder
}

\author{
Amit Kumar Pal ${ }^{1}$, Sagarika Ray ${ }^{2}$, Jishnu Bhattacharya ${ }^{3}$ \\ ${ }^{1}$ MBBS, MD Anatomy, Senior Resident in Department of Anatomy, Midnapore Medical College and Hospital, \\ West Bengal. \\ ${ }^{2}$ MBBS, MD Psychiatry, Senior Resident in Psychiatry, Institute of Psychiatry - Centre of Excellence, \\ IPGME\&R, Kolkata. \\ ${ }^{3}$ MBBS, DPM (WBUHS), DCMH, FOAM, DEMENTIA ECHO (NIMHANS), Consultant Neuropsychiatrist, \\ Suri Superspeciality Hospital, Suri, Birbhum, West Bengal
}

Corresponding Author: Sagarika Ray

\begin{abstract}
Background: Bipolar affective disorder is an episodic illness characterized by fluctuating mood states. Association of dermatoglyphic traits with bipolar affective disorder has been observed in various studies. This study was undertaken to evaluate epidermal ridge patterns in bipolar patients as compared to healthy controls attending a super speciality district hospital in West Bengal.

Context and purpose of study: Establishing dermatoglyphic parameters as biomarkers for early diagnosis and consequently, prompt intervention in bipolar affective disorder will ensure a greater scope of recovery, and thus promote a better quality of life for the individual as well as lower the burden of disease for the society.

Methods: Quantitative dermatoglyphic parameters namely, Total Finger Ridge Count (TFRC), Total A-B Ridge Count (TABRC), and ATD Angle of 100 bipolar patients were compared to 100 age and gender matched healthy controls.

Results: Statistically significant differences were found on comparing the dermatoglyphic parameters between cases and controls. TFRC was found to be decreased while ATD angle was increased in bipolar cases, as compared to the control group. However, no significant change was observed in TABRC between the two groups.

Conclusions: This study found a significant association between dermatoglyphic pattern anomalies and the development of bipolarity. This may offer a scope of primordial prevention of bipolar disorder in future.
\end{abstract}

Keywords: Dermatoglyphics, ridge pattern, bipolar disorder, Total Finger Ridge Count (TFRC), Total A-B Ridge Count (TABRC), ATD angle.

\section{INTRODUCTION}

Dermatoglyphics involves the study of epidermal ridge patterns and their configuration on digits, palms and soles. ${ }^{[1]}$ The term "dermatoglyphics" is derived from two root words. Greek word "derma" means skin and "glyph" translates into carvings. ${ }^{[2]}$ The mechanisms that govern ridge formation is complex and different hypotheses have been put forward to explain them. Kollmann and Bonnevie suggested that the interplay of different tensile force and stress factors determine the primary ridge formation. ${ }^{[3]}$ They observed that the basal epidermal cells were subjected to mechanical stress owing to their fast proliferation. These cells were driven towards the underlying dermis as a consequence of the compressive force resulting in the development of primary ridges. 
Harold Cummins postulated a link between dermatoglyphic pattern and hand geometry and the growth factors prevalent on embryonic skin. ${ }^{[4]}$ Kucken presented a mathematical model to calculate the stress factors responsible for specific ridge pattern. ${ }^{[5]}$ Kucken and Champod tested the impact of stress on Merkel cell at dermoepidermal junction by using the model and worked out the direction taken by Merkel cell due the resultant tension. The specific direction of Merkel cell movement may define the way in which the ridge pattern will be laid out. ${ }^{[6]}$

Studies also claim that the branching network of capillaries and nerves in the skin dictates the ridge topography. ${ }^{[7]}$ According to the fibroblast theorem, the tensile force which operates to generate ridge patterns are due to the involvement of fibroblasts. ${ }^{[8]}$ During the later half of the first trimester and the entire second trimester of intrauterine life, these ridge patterns are laid down and they are fully established at around the 7th month of intra uterine life. ${ }^{[2,9,10]}$ Studies have shown that dermatoglyphic formation is the result of interaction between genetic and environmental factors. ${ }^{[11]}$ A number of major genes along with some modifying genes bring about the velar patterning. The intra uterine environment plays a vital role in tissue differentiation and organogenesis. Hence any sort of prenatal insult, in the form of either infection, radiation, drugs, toxin or trauma will reflect as dermatoglyphic abnormality. ${ }^{[12]}$ Once fully formed, dermatoglyphic patterns stay unchanged throughout the lifetime of a person and are not affected by age or environment. ${ }^{[2,10]}$ The uniqueness, early differentiation and ease of obtaining and storage of fingerprints makes it a feasible tool to be studied in the context of certain pathological processes.

Mood disorders comprise of a spectrum of psychiatric disorders characterized by pathological mood states and concomitant vegetative and psychomotor disturbances. In contrast to the older term "affective disorders", the term "mood disorders" is now preferred because it is more representative of sustained emotional states and not a sheer reference to the external (affective) expression of the underlying (internal) emotional state. Mood disorders should be considered as syndromes and not merely discrete diseases as they deal with a plethora of signs and symptoms sustained over a period of weeks to months that cause a significant change from an individual's baseline functioning. Such periods tend to recur in the lifespan of an individual in a periodical or cyclical manner. Unipolar depression in the most common mood disorder encountered in clinical practice. ${ }^{[13]}$ Bipolar disorder, earlier known as manic-depressive psychosis comprises of a combination of manic, hypomanic, depressive and mixed episodes, interspersed by euthymic intervals.

A manic episode is characterized by an elevated or irritable mood. There are associated symptoms like inflated selfesteem, grandiosity, tall claims and big talks, sleeplessness, talkativeness, racing thoughts, distractibility, hyperactivity, singing and dancing on own, anger outbursts and reckless behaviour. A depressive episode is characterized by low mood, anhedonia and easy fatiguability. Other associated symptoms include sleep disturbances, psychomotor retardation or agitation, feelings of worthlessness or guilt, impaired thinking or concentration, change of appetite or weight and suicidal thoughts. Both manic and depressive episodes can present with or without psychotic symptoms. Hypomanic episode is one which presents with a less severe form of manic symptoms and does not cause socio occupational impairment for the individual. A mixed episode presents with symptoms pertaining both to mania and depression simultaneously in the same episode. ${ }^{[14,15]}$

Family, twin and adoption studies have documented that genes play an instrumental role in the susceptibility to mood disorders. However, genes merely pose a predisposition, which has to interact 
with environmental factors in order to cause the disease. Similarly the development of papillary ridge patterns is also affected by genetic and environmental milieu in uterus. Thus atypical dermatoglyphic pattern may suggest genetic or environmental abnormalities during the neurodevelopmental window. Keeping this in mind, the present study was conducted to find a possible correlation between dermatoglyphic parameters and bipolar disorder so that dermatoglyphics can serve as a predictive marker for bipolar disorder, even before the onset of florid symptoms.

\section{MATERIALS AND METHODS}

A cross-sectional study was carried out, with non-probability, purposive sampling.

Cases: The study included 100 individuals, aged between 18 to 60 years, who were diagnosed as bipolar affective disorder according to the ICD 10 criteria, $^{[14]}$ including 50 males and 50 females. Such cases were chosen from clients visiting the Psychiatry outpatient department at Suri Superspeciality Hospital, Suri, Birbhum, West Bengal, India.

Exclusion criteria: Patients with other mental illnesses, such as schizophrenia, schizoaffective disorder, acute transient psychotic disorders, dissociative [conversion] disorder, obsessive compulsive disorder, cognitive disorders, or substance use disorders, as well as those with related genetic abnormalities, or suffering from other comorbid illnesses were excluded from the research.

Controls: After screening with the General Health Questionnaire (12 item version), age and gender matched healthy controls were recruited from the community. A total of 100 controls were chosen, including 50 males and 50 females. It was ascertained that these individuals did not have any psychiatric disorders, other comorbid illnesses, or a family history of psychiatric disorders.
The purpose and procedure of the study was clearly described to the research participants in details in their native language, and only those who voluntarily consented were included in the study. After receiving ethical approval, the study was carried out over a period of six months. The research was self-funded.

\section{Procedure to obtain digito-palmar prints:} Study participants were asked to clean their hands with soap and water to remove dirt. Palmar prints were taken by standard ink method. A glass slab was placed on the table. A small amount of Kores duplicating ink was spread over it with a roller to produce a thin, uniform film of ink which was applied to palmar aspect of both hands starting from wrist creases to fingertips. The hand was extended at wrist joint and was kept on paper. Pressure was applied on the head of metacarpals, dorsum of hand and web space between fingers. Complete palm impression including the hollow of the palm was obtained on paper and then individual fingertip print was taken by rolling it on the paper.

Ridge arrangement on fingers: In the simplest classification (Galton 1892) finger print patterns are divided into three main classes which namely arches, loops and whorls. (Refer Figure 1)

The loop is defined as a pattern where ridges enter from one side of the finger and curve back on itself to leave through the same side. Loops are further subdivided into radial and ulnar variety based on the side of the finger in which they open. (Refer Figure 2) In a whorl, the ridges circuit around the central core. Arches represent a pattern where the ridges enter from one side of the finger and leave through the other side, with an elevation in between.

A triradius is seen at the site of confluence of three ridge systems. A simple arch has no triradius. A loop has one triradius. Ulnar loop has triradius on the radial side while radial loop has it on the 
ulnar side. In a whorl, typically there are

two triradii. (Refer Figure 1 and Figure 3)

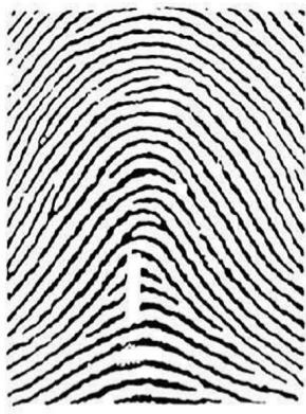

Arch (No Triradius)

Finger Ridge Count 0

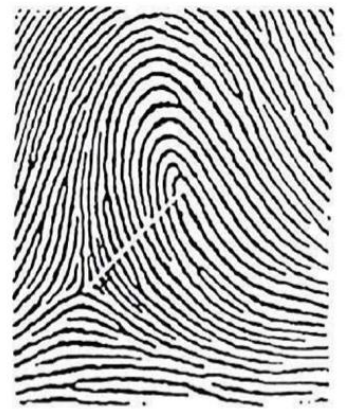

Loop (One Triradius)

Finger Ridge Count 13

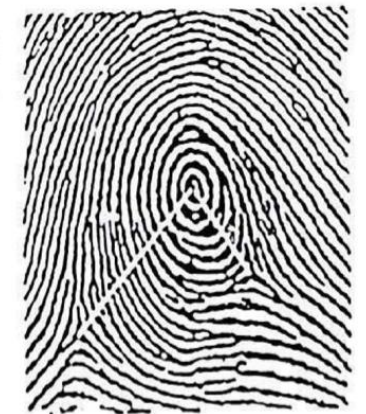

Whorl (Two Triradii)

Finger Ridge Count 17 (on left)

8 (on right)

Figure 1. Ridge patterns with associated triradius and finger ridge count.

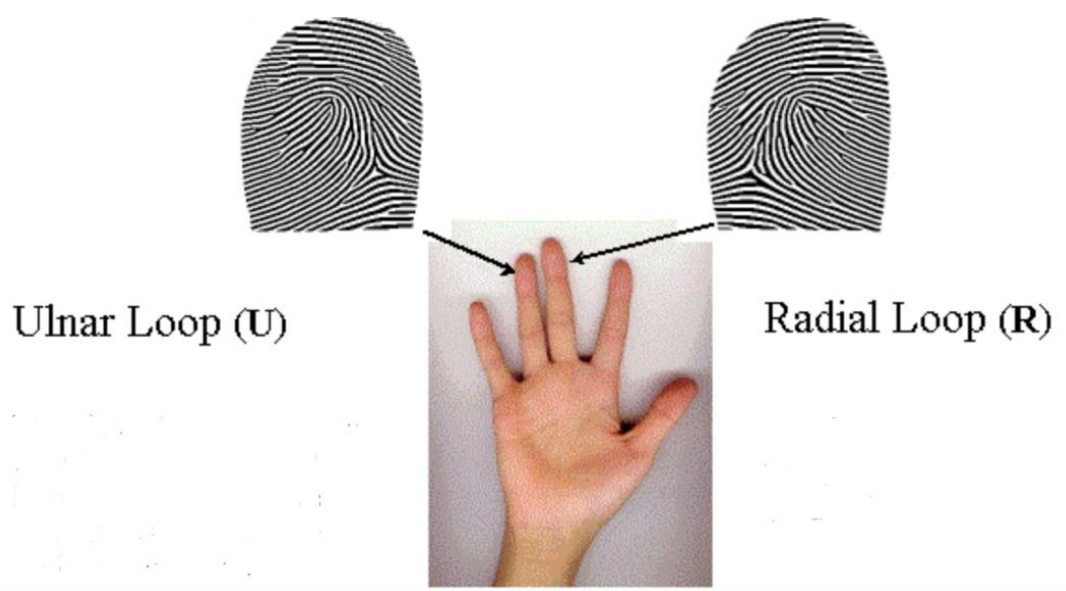

Figure 2. Radial loop and ulnar loop.

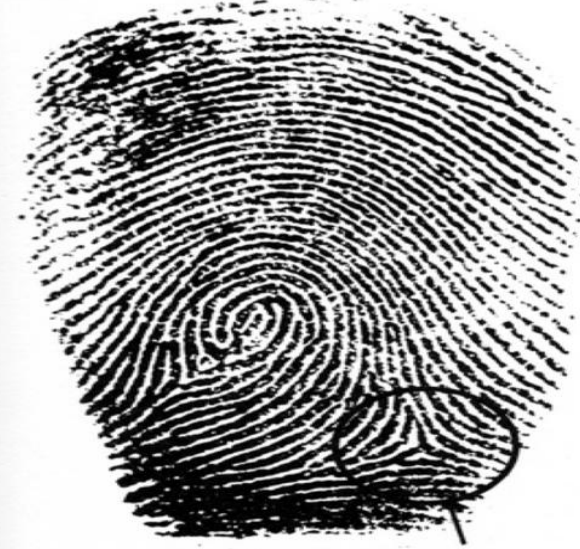

Figure 3. Digital triradius

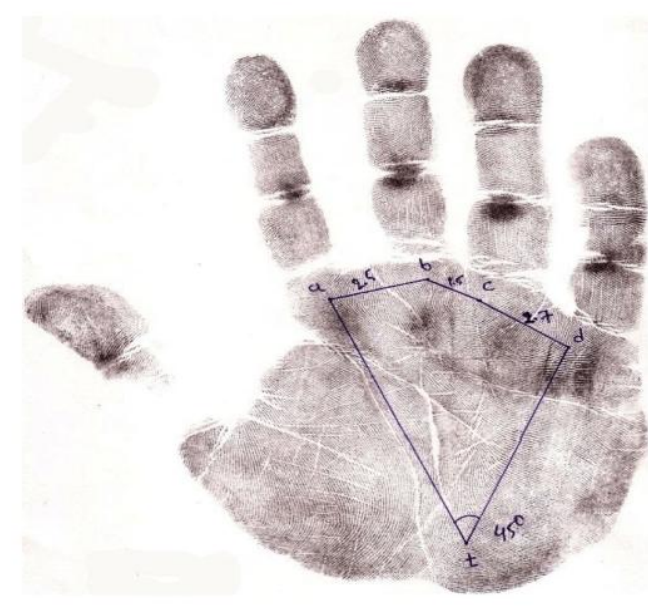

Figure 4. ATD angle and A-B ridge count.
Total Finger Ridge Count - In a simple arch as there is no triradius, therefore ridge count score is 0 . A loop with one triradius has one line of count. In case of whorls there are typically two lines of counts. In a symmetrical whorl one line is taken from each triradius to the centre. In the double loop type of whorl, one line is taken from each triradius to the corresponding core. In our study only the higher count (corresponding to the longer line) has been used in case of whorl. The sum of the single 
counts on all the ten fingers of an individual is the total finger ridge count (TFRC).

'A-B' Ridge Count - 'A-B' Ridge Count is the number of ridges occurring in the second interdigital area between the digital triradii $a$ and $b$, at the base of index and middle fingers respectively. (Refer Figure 4) All ridges which are cut or touched by a straight line between the triradii are counted.

'ATD' angle - It is the angle measured in degrees between the lines obtained by joining digital triradius ' $a$ ' at the base of index finger to the axial triradius ' $t$ ' in between thenar and hypothenar eminence and from this to digital triradius ' $d$ at the base of little finger. (Refer Figure 4)

\section{Dermatoglyphic parameters recorded:}

1. Total Finger Ridge Count (TFRC)
2. Total A-B Ridge Count (TABRC)

3. Finger Ridge Count (FRC) of right and left hands separately

4. A-B Ridge Count (ABRC) of right and left hands separately

5. ATD angles of right and left hands.

The above parameters were studied in both cases and controls. All measurements were taken twice to prevent observational errors.

\section{RESULTS AND STATISTICAL ANALYSIS}

Data collected was entered into Microsoft Excel spreadsheet which was used to prepare the data chart. Appropriate statistical tools were used to analyze the results. Two tailed unpaired t-test was used to compare the means of case and control groups. Statistical significance was set at $\mathrm{p}$ value less than 0.05 , using $95 \%$ confidence intervals.

Table 1: Comparison of Total Finger Ridge Count (TFRC) between cases and controls
\begin{tabular}{|l|l|l|l|l|l|}
\hline Subjects & Mean & Maximum & Minimum & Standard Deviation & p value \\
\hline Case $(n=100)$ & 106.03 & 142 & 74 & 17.53 & $<0.0001$ \\
\hline Control $(n=100)$ & 137.89 & 150 & 121 & 8.15 & \\
\hline
\end{tabular}

Table 2: Comparison of Finger Ridge Count (FRC) in right and left hands in cases and controls

\begin{tabular}{|l|l|l|l|l|l|c|}
\hline & Subjects & Mean & Maximum & Minimum & Standard Deviation & p value \\
\hline \multirow{2}{*}{ Right FRC } & Case $(\mathrm{n}=100)$ & 53.06 & 72 & 35 & 8.79 & $<0.0001$ \\
\cline { 2 - 7 } & Control $(\mathrm{n}=100)$ & 68.75 & 70 & 60 & 4.45 & \\
\hline \multirow{2}{*}{$\begin{array}{l}\text { Left } \\
\text { FRC }\end{array}$} & Case $(\mathrm{n}=100)$ & 52.96 & 74 & 34 & 9.07 & $<0.0001$ \\
\cline { 2 - 6 } & Control $(\mathrm{n}=100)$ & 69.14 & 76 & 60 & 4.17 & \\
\hline
\end{tabular}

Table 1 compares the Total Finger Ridge Count (TFRC) between bipolar patients and controls. Figures in brackets indicate the standard deviations. Mean TFRC in cases was found to be 106.03 $( \pm 17.53)$ while that in controls was 137.89 $( \pm 8.15)$. TFRC was found to significantly lower in bipolar patients than in healthy controls.
Table 2 further demonstrates the Finger Ridge Count (FRC) separately in right and left hands. The mean FRC in right hand was $53.06( \pm 8.79)$ and $68.75( \pm 4.45)$ in cases and controls respectively. The mean FRC in left hand was found to be 52.96 $( \pm 9.07)$ and $69.14( \pm 4.17)$ in cases and controls respectively. FRC in each hand was also found to be significantly lower in bipolar patients as compared to controls.

Table 3: Comparison of Total A-B Ridge Count (TABRC) between cases and controls

\begin{tabular}{|l|l|l|l|l|l|}
\hline Subjects & Mean & Maximum & Minimum & Standard Deviation & p value \\
\cline { 1 - 5 } Case $(\mathrm{n}=100)$ & 80.61 & 85 & 71 & 3.14 & 0.9641 \\
not significant
\end{tabular}

Table 4: Comparison of A-B Ridge Count (ABRC) in right and left hands in cases and controls

\begin{tabular}{|l|l|l|l|l|l|l|}
\hline & Subjects & Mean & Maximum & Minimum & Standard Deviation & p value \\
\hline \multirow{2}{*}{ Right ABRC } & Case $(\mathrm{n}=100)$ & 39.97 & 45 & 34 & 2.09 & 0.9459 \\
\cline { 2 - 8 } & Control $(\mathrm{n}=100)$ & 39.99 & 45 & 35 & 2.07 & not significant \\
\hline \multirow{2}{*}{$\begin{array}{l}\text { Left } \\
\text { ABRC }\end{array}$} & Case $(\mathrm{n}=100)$ & 40.64 & 45 & 36 & 2.14 & 0.8699 \\
\cline { 2 - 7 } & Control $(\mathrm{n}=100)$ & 40.69 & 46 & 36 & 2.17 & not significant \\
\hline
\end{tabular}


Table 3 summarizes the Total A-B Ridge Count (TABRC), which shows the mean TABRC to be $80.61( \pm 3.14)$ and 80.68 $( \pm 3.14)$ in cases and controls respectively. There was no statistically significant difference in TABRC between bipolar patients as compared to controls.

Table 4 further elaborates the A-B Ridge Count (ABRC) individually in right and left hands. Mean ABRC in right hand in cases and controls was found to be 39.97 $( \pm 2.09)$ and $39.99( \pm 2.07)$ respectively. Mean ABRC in left hand was found to be $40.64 \quad( \pm 2.14)$ and $40.69 \quad( \pm 2.17)$ respectively in cases and controls. ABRC was not found to be significantly altered in each hand separately in bipolar patients with respect to the healthy controls.

Table 5: Comparison of ATD angle in right and left hands in cases and controls

\begin{tabular}{|l|l|l|l|l|l|c|}
\hline & Subjects & Mean & Maximum & Minimum & Standard Deviation & p value \\
\hline \multirow{2}{*}{ Right ATD angle } & Case $(\mathrm{n}=100)$ & $42.48^{\circ}$ & $52^{\circ}$ & $31^{\circ}$ & 5.67 & $<0.0001$ \\
\cline { 2 - 7 } & Control $(\mathrm{n}=100)$ & $38.98^{\circ}$ & $50^{\circ}$ & $31^{\circ}$ & 5.74 & $<0.0001$ \\
\hline \multirow{2}{*}{$\begin{array}{l}\text { Left } \\
\text { ATD angle }\end{array}$} & Case $(\mathrm{n}=100)$ & $43.3^{\circ}$ & $51^{\circ}$ & $32^{\circ}$ & 5.67 & \\
\cline { 2 - 7 } & Control $(\mathrm{n}=100)$ & $38.59^{\circ}$ & $49^{\circ}$ & $30^{\circ}$ & 4.74 & \\
\hline
\end{tabular}

Table 5 compares the ATD angles in each hand separately. Mean ATD angle in right hand was found to be $42.48^{\circ}( \pm 5.67)$ and $38.98^{\circ}( \pm 5.74)$ in cases and controls respectively. Mean ATD angle in left hand was found to be $43.3^{\circ}( \pm 5.67)$ and $38.59^{\circ}$ $( \pm 4.74)$ in cases and controls respectively. ATD angle was found to be significantly increased in bipolar patients in each hand as compared to controls.

\section{DISCUSSIONS}

Both family and twin studies have established the genetic basis of bipolar disorder. Family studies indicate that in contrast to $1 \%$ disease rate in the general population, there is a seven fold higher rate of morbid illness in first degree relatives of bipolar patients. ${ }^{[16]}$ Familial studies however can not distinguish whether the familial transmission was facilitated by genetic or environmental factors, since individuals of the same family also share similar environmental variables like exposure to infectious agents, toxins and other brain insults, high expressed emotion, dysfunctional interpersonal relationships and resultant stress, geographical migration, role transitions, bereavement, influence of substance use, socio-economic status etc. Twin studies serve as an useful tool to differentiate "nature" from "nurture" and specifically implicate whether genetics or environmental factors have played the role in disease transmission. Such studies have found a two to four fold increase in concordance rate for mood disorder in monozygotic twins as compared to dizygotic twins. ${ }^{[16]}$ This clearly indicates the significant role of genetic factors in disease causation.

Linkage regions implicated in the transmission of bipolar illness include $4 p$, $6 \mathrm{q}, 8 \mathrm{q}, 13 \mathrm{q}, 16 \mathrm{p}, 18 \mathrm{p}, 18 \mathrm{q}, 21 \mathrm{q}, \mathrm{Xq}, 22 \mathrm{q} .{ }^{[16-}$ ${ }^{19]}$ Some studies have shown association of $1 \mathrm{q}, 2 \mathrm{p}, \quad 6 \mathrm{q}$ and $14 \mathrm{q}$ with hyperthymic temperament, $3 p$ and $13 q$ with dysthymic temperament and $6 \mathrm{q}$ with irritable temperament. ${ }^{[16,20]}$ Candidate genes involved in bipolar disorder include SCL6A3, SCL6A4, HTR4, DRD4, DRD2, HTR2A, MAOA, DISC1, DTNBP1, NRG1, BDNF, DAOA and COMT. ${ }^{[16,21,22]}$

There has been a persistent debate over the last few years as to whether schizophrenia and bipolar disorder should warrant two separate and distinct diagnoses, or whether they should be considered as disorders of the same spectrum with similar underlying etio-pathogenesis. ${ }^{[23]}$ According to some researchers, bipolar disorder should also be considered as a neurodevelopmental disorder, analogous to schizophrenia. ${ }^{[24,25]} \mathrm{A}$ growing body of evidence indicates that structural brain abnormalities are linked to both schizophrenia and bipolar disorder, resulting from an interaction between genetic and obstetric risk factors. ${ }^{[26-31]}$

A number of studies similar to the present study have been performed by 
researchers in order to assess whether dermatoglyphic parameters have a bearing with development of bipolar affective disorder.

Balgir et al. (1980) studied qualitative and quantitative dermatoglyphic characteristics in manic-depressive psychosis. They observed that bipolar patients had a slightly lower mean A-B ridge count when compared to controls but it was not statistically significant. Similarly there was no significant difference in total finger ridge count between cases and controls. However ATD angle was found to be significantly lower in bipolar cases than in controls. ${ }^{[32]}$

Gutiérrez B et al. (1998) examined dermatoglyphic characteristics viz. total A$\mathrm{B}$ ridge count and total finger ridge count in patients with bipolar disorder as per DSM III - $\mathrm{R}$ criteria and compared them with healthy controls. There were no differences observed in these two parameters. ${ }^{[33]}$

Jelovac $\mathrm{N}$ et al. evaluated dermatoglyphics in bipolar patients and healthy controls, noting that the mean Total Finger Ridge Count in bipolar cases was significantly lower than that in control groups, which is in line with our observation in this study. However they also found a significant decrease in both right and left AB Ridge Count, as well as in ATD angle in bipolar cases than in controls, as opposed to our findings. ${ }^{[34]}$

Yousefi-Nooraie R et al. concluded that there was no significant difference in Total Finger Ridge Count, A-B Ridge Count and ATD angle in cases of bipolar disorder when compared to controls. ${ }^{[35]}$

Chakraborty D et al. demonstrated that atd angle was increased in bipolar patients but it was not statistically significant. ${ }^{[36]}$

Srivastava et al. found that the Total Finger Ridge Count was significantly reduced only in male patients of bipolar disorder, but not in case of females. ATD angle was found to be significantly increased in the cases as compared to controls. However, there was no significant difference in A-B Ridge Count. These findings are in accordance to our observation in the present study. ${ }^{[37]}$

Hiremath et al. reported a significant decrease in Total Finger Ridge Count and increased ATD angle in bipolar cases than in controls, which is similar to our findings. However they also observed a significant decrease in A-B Ridge Count in both hands in bipolar cases as opposed to our study. ${ }^{[38]}$

\section{CONCLUSION}

Dermatoglyphics being a noninvasive approach, might prove to be useful as a screening tool for individuals at risk of developing bipolar affective disorder, especially in those having a family history of this illness. Further studies in larger scale are required to firmly establish it as a reliable marker, so that it can facilitate diagnosis and improve the long term prognosis of bipolar affective disorder.

\section{Abbreviations}

TFRC: Total Finger Ridge Count

TABRC: Total A B Ridge Count

FRC: Finger Ridge Count

ABRC: A B Ridge Count

ICD: International Classification of Diseases

DSM: Diagnostic and Statistical Manual of Mental Disorders

\section{ACKNOWLEDGEMENT}

We sincerely thank our respective Heads of the department- Professor Dr. Pradeep Kumar Saha, Director, IOP-COE, Kolkata and Professor Dr. Sumohan Biswas, HOD Anatomy, Midnapore $\mathrm{MCH}$ for their wholehearted support.

\section{Conflict of Interest: None}

\section{Source of Funding: None}

Ethical Approval: Approved

\section{REFERENCES}

1. Cummins H, Midlo C. Finger prints, palms and soles: An introduction to 
dermatoglyphics. New York Dover publication, 1961; 177-8.

2. Kiran K, Kavitha R, Amitha HM. Dermatoglyphics as a non-invasive diagnostic tool in predicting mental retardation. J Int Oral Health 2010;2:95100.

3. Bonnevie K. Studies on papillary patterns in human fingers. J Genet 1924;15:1-111.

4. Cummins H. Epidermal-ridge configurations in developmental defects, with particular reference to the ontogenetic factors which condition ridge direction. Am J Anat 1926;38:89-151.

5. Kücken M. Models for fingerprint pattern formation. Forensic Sci Int 2007;171:85-96.

6. Kücken M, Champod C. Merkel cells and the individuality of friction ridge skin. $\mathrm{J}$ Theor Biol 2013;317:229-37.

7. Moore SJ, Munger BL. The early ontogeny of the afferent nerves and papillary ridges in human digital glabrous skin. Dev Brain Res 1989;48:119-41.

8. Fleury V, Watanabe T. About the equilibrium shape of fibred structures, and biological shape. CR Biol 2004;327:663-77.

9. Namouchi I. Anthropological significance of dermatoglyphic trait variation: An intraTunisian population analysis. Int $\mathrm{J}$ Mod Anthropol 2011;4:12-27.

10. Kumbnani HK. Dermatoglyphics. In: Bhasin V, Bhasin MK, editors. Delhi: Kamla-Raj Enterprises; 2007.

11. Chakraborty, R. The Role of Heredity and Environment on Dermatoglyphic Traits. In Dermatoglyphics: Science in Transition; March of Dimes: Washington, DC, 1991; pp 151-191.

12. Łopuszańska M, Jankowska EA. Dermatoglyphic morphology in some diseases. Pol Merkur Lekarski. 2001 Sep;11(63):282-6. Polish. PMID: 11761831.

13. Akiskal HS. Mood Disorders: Historical Introduction and Conceptual Overview. In: Sadock BJ, Sadock VA, Ruiz P. Kaplan \& Sadock's Comprehensive Textbook of Psychiatry. 10th Ed. Philadelphia: Wolters Kluwer; 2017, Volume 1 Chapter 13.1

14. The ICD-10 Classification of Mental and Behavioural Disorders - Clinical descriptions and diagnostic guidelines. World Health Organization, 91-109

15. American Psychiatric Association: Diagnostic and Statistical Manual of Mental
Disorders, 5th Ed. Arlington: American Psychiatric Publishing; 2013, 123-154

16. Kelso JR, Greenwood TA. Mood Disorders: Genetics. In: Sadock BJ, Sadock VA, Ruiz P. Kaplan \& Sadock's Comprehensive Textbook of Psychiatry. 10th Ed. Philadelphia: Wolters Kluwer; 2017, Volume 1 Chapter 13.3

17. Segurado R, Detera-Wadleigh SD, Levinson $\mathrm{DF}$ et al: Bipolar disorder. Am J Hum Genet. 2003 Jul;73(1):49-62. doi: 10.1086/376547. Epub 2003 Jun 11. PMID: 12802785; PMCID: PMC1180589.

18. Badner JA, Gershon ES. Meta-analysis of whole-genome linkage scans of bipolar disorder and schizophrenia. Mol Psychiatry. 2002;7(4):405-11. doi: 10.1038/sj.mp.4001012. PMID: 11986984.

19. McQueen MB, Devlin B, Faraone SV, et al. Combined analysis from eleven linkage studies of bipolar disorder provides strong evidence of susceptibility loci on chromosomes 6q and 8q. Am J Hum Genet. 2005;77(4):582-595. doi:10.1086/491603

20. Greenwood TA, Akiskal HS, Akiskal KK; Bipolar Genome Study, Kelsoe JR. Genome-wide association study of temperament in bipolar disorder reveals significant associations with three novel Loci. Biol Psychiatry. 2012;72(4):303-310. doi:10.1016/j.biopsych.2012.01.018

21. Craddock N, O'Donovan MC, Owen MJ. Genes for schizophrenia and bipolar disorder? Implications for psychiatric nosology. Schizophr Bull. 2006;32(1):9-16. doi:10.1093/schbul/sbj033

22. Escamilla MA, Zavala JM. Genetics of bipolar disorder. Dialogues Clin Neurosci. 2008;10(2):141-152. doi:10.31887/DCNS.2008.10.2/maescamilla

23. Demjaha A, MacCabe JH, Murray RM. How Genes and Environmental Factors Determine the Different Neurodevelopmental Trajectories of Schizophrenia and Bipolar Disorder. Schizophrenia Bulletin 2012; 38, 209-214.

24. Blumberg HP, Kaufman J, Martin A et al. Significance of adolescent neurodevelopment for the neural circuitry of bipolar disorder. Annals of the New York Academy of Sciences 2004; Jun. 1021, 37683.

25. Van Os J, Jones $P$, Lewis $G$ et al. Developmental precursors of affective illness in a general population birth 
cohort. Arch Gen Psychiatry. 1997;54(7):625-631. doi:10.1001/archpsyc.1997.0183019004900 5

26. Kempton MJ, Geddes JR, Ettinger U et al. Meta-analysis, database, and metaregression of 98 structural imaging studies in bipolar disorder. Archives of General Psychiatry 2008; 65(9), 1017-1032.

27. Hallahan B, Newell J, Soares JC et al. Structural magnetic resonance imaging in bipolar disorder: an international collaborative mega-analysis of individual adult patient data. Biological Psychiatry 2011; 69, 326-335.

28. McDonald C, Bullmore ET, Sham PC et al. Association of genetic risks for schizophrenia and Bipolar Disorder with specific and generic brain structural endophenotypes. Archives of General Psychiatry 2004; 61, 974-984.

29. Pantelis C, Yucel M, Wood SJ et al. Structural brain imaging evidence for multiple pathological processes at different stages of brain development in schizophrenia. Schizopheniar Bulletin 2005; 31(3), 672-696.

30. Shenton ME, Dickey CC, Frumin M et al. A review of MRI findings in schizophrenia. Schizophrenia Research 2001;49(1-2),1-52.

31. Wright IC, Rabe-Hesketh S, Woodruff PW et al. Meta-analysis of regional brain volumes in schizophrenia. American Journal of Psychiatry 2000; 157(1),16-25.

32. Balgir RS, Murthy RS, Wig NN. Manicdepressive psychosis and schizophrenia: A dermatoglyphic study. Br J Psychiatry 1980 Jun;136:558-61.
33. Gutiérrez B, Van Os J, Vallès V et al. Congenital dermatoglyphic malformations in severe bipolar disorder. Psychiatry Res 1998;78:133- 40.

34. Jelovac $N$, Milicic J, Milas $M$ et al. Dermatoglyphic analysis in bipolar affective disorder and schizophrenia- "continuum of psychosis" hypothesis corroborated? Collegium Antropologicum 1999;23(2):58995.

35. Yousefi-Nooraie R, Mortaz-Hedjri S. Dermatoglyphic asymmetry and hair whorl patterns in schizophrenic and bipolar patients. J.Psychiatry Research 2008;157: 247-250.

36. Chakraborty D, Mazumdar P, Than M et al. Dermatoglyphic analysis in Malay subjects with bipolar mood disorder. Med J Malaysia 2001,56:223-226.

37. Shrivastava M, Mathur RK, Dhaneria V et al. Dermatoglyphic Study in Bipolar Disorder.Indian Journal of Clinical Anatomy and Physiology, April-June 2016;3(2);243-247

38. Hiremath R, Begum N, Desai SD et al. Dermatoglyphic Analysis in Indian Subjects with Manic Depressive Psychosis: A Prospective Study. Indian Journal of Anatomy. $2018.707-411$. 10.21088/ija.2320.0022.7418.10.

How to cite this article: Pal AK, Ray S, Bhattacharya J. Use of dermatoglyphic parameters as possible markers in bipolar affective disorder. Int J Health Sci Res. 2021; 11(7):385-393. DOI: https://doi.org/10.52403/ ijhsr.20210753 